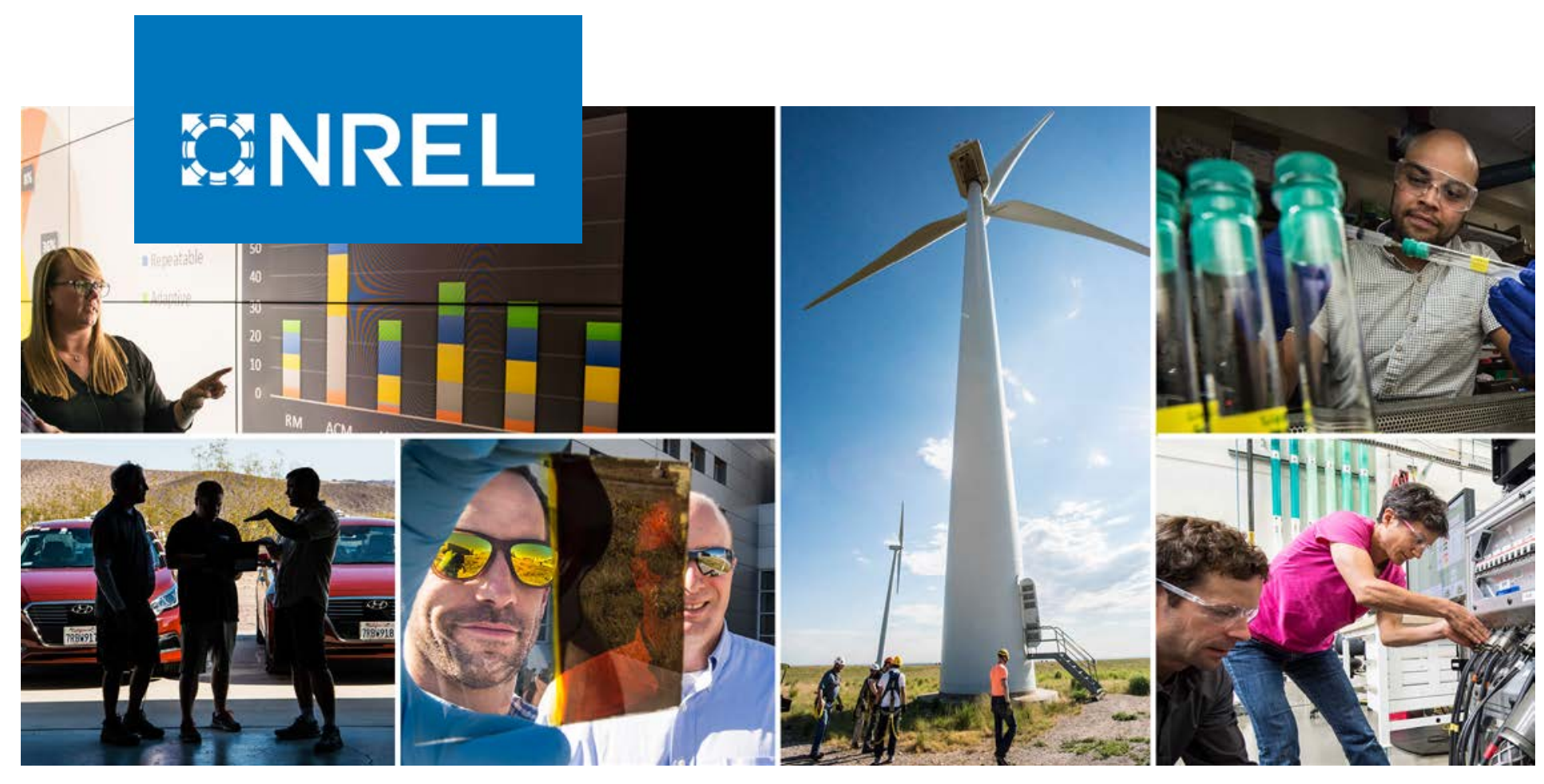

\title{
On-Road Fuel Cell Electric Vehicles Evaluation: Overview
}

Jennifer Kurtz, Sam Sprik, Genevieve Saur, and Shaun Onorato

National Renewable Energy Laboratory

NREL is a national laboratory of the U.S. Department of Energy

Office of Energy Efficiency \& Renewable Energy

Operated by the Alliance for Sustainable Energy, LLC

This report is available at no cost from the National Renewable Energy Laboratory (NREL) at www.nrel.gov/publications.
Technical Report

NREL/TP-5400-73009

March 2019 


\section{GNREL}

\section{On-Road Fuel Cell Electric Vehicles Evaluation: Overview}

Jennifer Kurtz, Sam Sprik, Genevieve Saur, and Shaun Onorato

National Renewable Energy Laboratory

\section{Suggested Citation}

Kurtz, Jennifer, Sam Sprik, Genevieve Saur, and Shaun Onorato. 2019. On-Road Fuel Cell Electric Vehicles Evaluation: Overview. Golden, CO: National Renewable Energy Laboratory. NREL/TP-5400-73009. https://www.nrel.gov/docs/fy19osti/73009.pdf.

NREL is a national laboratory of the U.S. Department of Energy Office of Energy Efficiency \& Renewable Energy Operated by the Alliance for Sustainable Energy, LLC

This report is available at no cost from the National Renewable Energy Laboratory (NREL) at www.nrel.gov/publications.

Contract No. DE-AC36-08GO28308
Technical Report NREL/TP-5400-73009 March 2019

National Renewable Energy Laboratory 15013 Denver West Parkway Golden, CO 80401 303-275-3000 • www.nrel.gov 


\section{NOTICE}

This work was authored by the National Renewable Energy Laboratory, operated by Alliance for Sustainable Energy, LLC, for the U.S. Department of Energy (DOE) under Contract No. DE-AC36-08GO28308. Funding provided by U.S. Department of Energy Office of Energy Efficiency and Renewable Energy Fuel Cell Technologies Office. The views expressed herein do not necessarily represent the views of the DOE or the U.S. Government.

This report is available at no cost from the National Renewable Energy Laboratory (NREL) at www.nrel.gov/publications.

U.S. Department of Energy (DOE) reports produced after 1991 and a growing number of pre-1991 documents are available free via www.OSTI.gov.

Cover Photos by Dennis Schroeder: (clockwise, left to right) NREL 51934, NREL 45897, NREL 42160, NREL 45891, NREL 48097, NREL 46526.

NREL prints on paper that contains recycled content. 


\section{Acknowledgements}

This work was supported by the U.S. Department of Energy Fuel Cell Technologies Office in the Office of Energy Efficiency and Renewable Energy. 


\section{List of Acronyms}

CDP

DOE

EPA

FCEV

FCTO

ICE

LD

NFCTEC

NREL

OEM composite data product

U.S. Department of Energy

U.S. Environmental Protection Agency

fuel cell electric vehicle

Fuel Cell Technologies Office

internal combustion engine

Learning Demonstration

National Fuel Cell Technology Evaluation Center

National Renewable Energy Laboratory

original equipment manufacturer 


\section{Table of Contents}

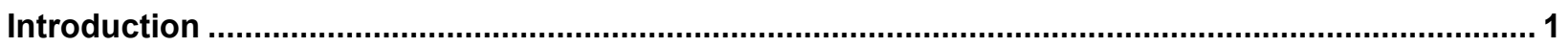

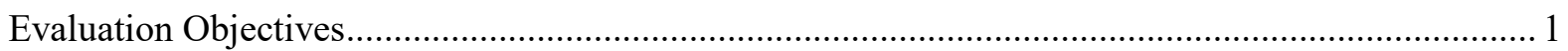

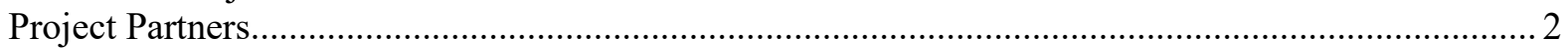

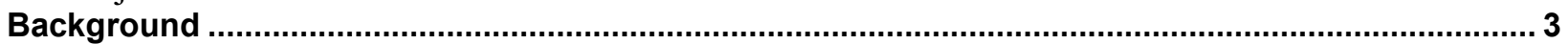

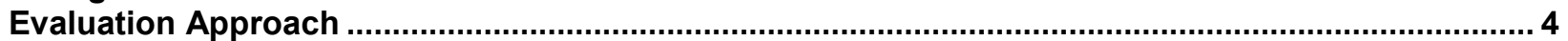

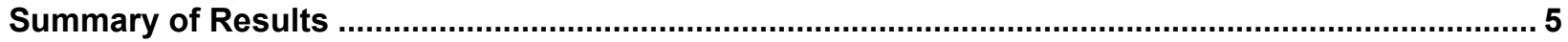

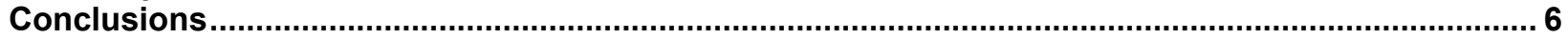

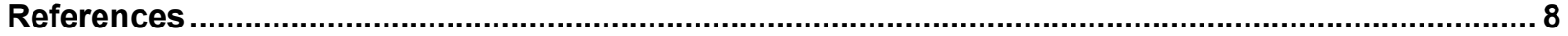

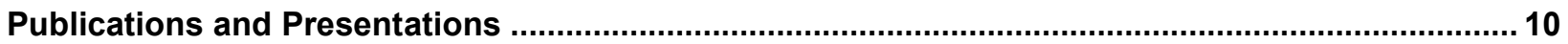

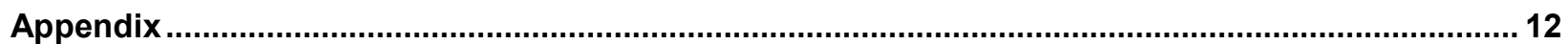




\section{Introduction}

This report presents an overview of an evaluation of on-road fuel cell electric vehicles (FCEVs) by the National Renewable Energy Laboratory (NREL) that has been ongoing since the U.S. Department of Energy Fuel Cell Technologies Office Learning Demonstration project began in 2005. The project addressed the need for current, on-road FCEV data and sought to validate improved performance and longer durability from comprehensive sets of early-stage FCEVs.

This report provides an overview of the evaluation project and partners, describes NREL's evaluation approach, and presents a summary of the results. Detailed results for durability, fuel economy, deployment and driving behavior, and specifications are published in separate reports.

\section{Evaluation Objectives}

NREL supports the U.S. Department of Energy (DOE) in the technical evaluation of hydrogen FCEVs under real-world conditions to address a lack of fuel cell electric vehicle performance and durability data. This is accomplished through evaluating and analyzing data from FCEVs in real-world, on-road operation to identify the current status of the technology, compare it to DOE program targets, and assist in evaluating progress between multiple generations of FCEV technology, some of which include commercial FCEVs for the first time. DOE set a technical target to validate hydrogen fuel cell electric vehicles with greater than 300-mile range and 5,000 hours fuel cell durability, by 2019, which is on part with current light-duty vehicle technology and customer expectations (DOE 2015).

DOE has funded projects for the collection and delivery of FCEV data to NREL's National Fuel Cell Technology Evaluation Center (NFCTEC) for analysis, aggregation, and reporting since 2003. NREL's NFCTEC plays a crucial role in NREL's independent, third party analysis and validation of proprietary technologies in real-world operation.

The general evaluation objectives are similar for all applications analyzed at the NFCTEC. These high-level objectives are to:

- Validate technology performance against DOE technical targets

- Provide feedback into early-stage research and development

- Independently assess technologies

- Evaluate performance metrics that are important to customers, government and other decision makers, supply chain operators, authorities having jurisdiction, and investors and developers

- Report on FCEV performance to support fuel cell and hydrogen research in areas such as safety, codes, and standards, market transformation, and production and delivery

- Investigate time-based performance (changes over time) and utilization-based performance (changes as the demand and usage increase).

The evaluation objectives can also be expressed in terms of performance categories and why those categories are relevant. While these categories may be consistent across multiple applications analyzed at NFCTEC, the details of why and how these are important tend to be specific to an application. 
The specific analysis categories for the FCEV evaluation include fuel cell stack durability, deployment, system specifications, range, fuel economy, efficiency, fill performance, reliability, drive and fill behaviors, power and energy management, fuel cell transients, benchmarking against technical targets and typical gasoline vehicle operation, maintenance, on-board storage, and safety, as well as identification of technology benefits, technology gaps, and comparison with current transportation technologies when possible.

\section{Project Partners}

Under DOE's Funding Opportunity Announcement DE-FOA-0000625, DOE funded industry partners to collect and deliver FCEV data to NREL for aggregation, analysis, and reporting. The project partners included six OEMs: General Motors (GM), Honda, Hyundai, Mercedes-Benz, Nissan, and Toyota. The latter three OEMs are part of one DOE project to Electricore. Each project partner had more than one vehicle included in this evaluation project, referred to as an FCEV fleet, for a total of six fleets. These vehicles are a mixture of pre-commercial and commercial vehicles, operated within fleets and by individual drivers, with model years from 2005 to 2012. The Toyota Mirai and Hyundai Nexo were not included in the analysis due to lack of data contribution and/or model year not being available during the evaluation timeline. The OEMs supply on-road vehicle data to NREL for evaluation at least every 3 months.

In 2017 the number of OEMs supplying data from on-road FCEVs for analysis decreased to three participants - Honda, Hyundai, and Mercedes-Benz - with vehicles spanning model years 2008 to 2016. In this phase, NREL's analysis focused on tracking progress and fueling performance to help inform capabilities, needs, and gaps at the interface between the FCEV and hydrogen fueling station. See Appendix for aggregated vehicle specifications.

Figure 1 shows representative images of the vehicles included in the two phases of the performance evaluation project.

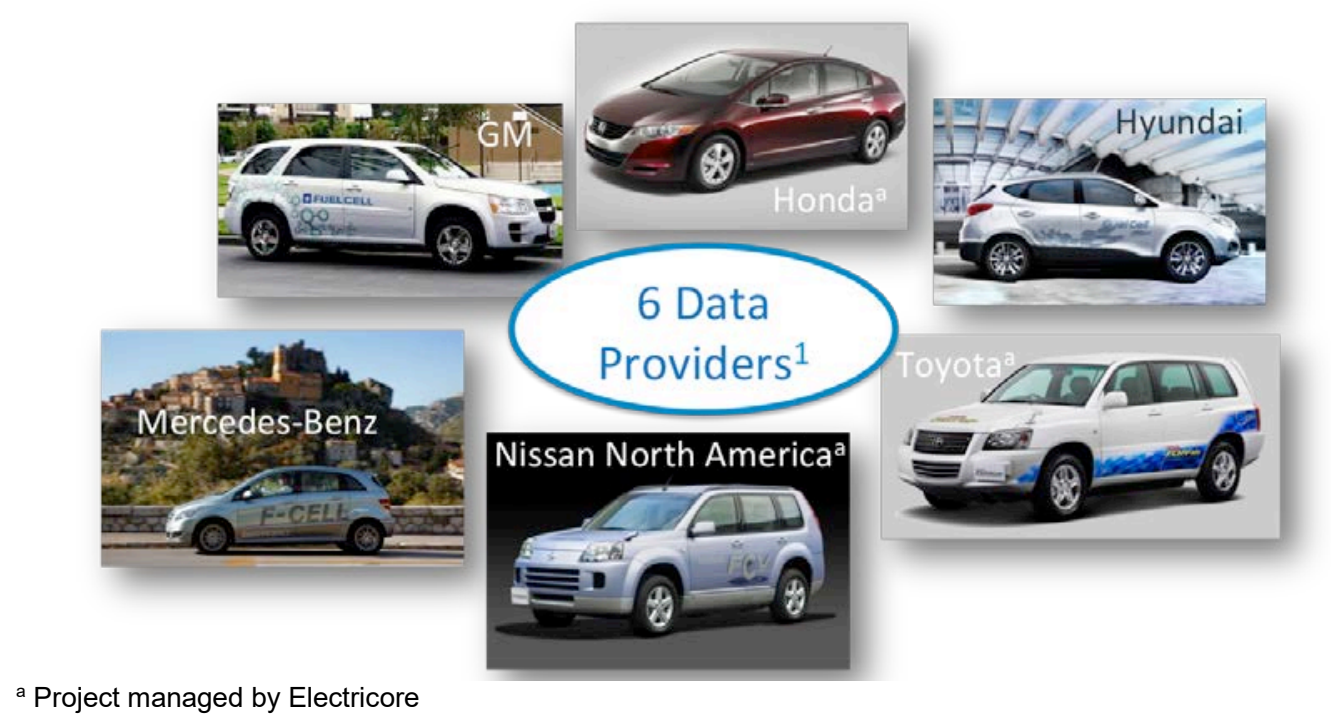

Figure 1. NFCTEC fuel cell electric vehicle evaluation project partners 


\section{Background}

FCEVs are engineered to meet many of the consumer acceptability requirements for transportation including range, fueling time, durability (Wilson, Marcinkoski, and Papageorgopoulos 2016b), and ease of operation. FCEVs are more efficient than conventional internal combustion engine (ICE) vehicles and emit only water vapor and warm air as tailpipe emissions. The ranges of operation of FCEVs are comparable to those of conventional ICE vehicles with fast fueling times (Wipke et al. 2012) and competitive market prices (with lease and purchase options) (Wilson, Marcinkoski, and Papageorgopoulos 2016a; Carlson et al. 2002; Davis 2006). These attributes, along with the necessary hydrogen infrastructure, allow FCEVs to support the diversification of U.S. energy sources, energy security, and the reduction of harmful emissions in the U.S. transportation sector.

Light-duty FCEVs for personal and fleet applications have been in limited production since the early 2000s. Some FCEV manufacturers (Toyota, Hyundai, and Honda) are now selling commercial production vehicles (Trainor and Joyce 2016; Hartline and Ingram 2015; Fuel Cells Bulletin 2016). Other manufacturers have been leasing pre-commercial FCEVs (MercedesBenz), have FCEVs in various development phases (GM and Nissan), or are in partnerships to develop commercial FCEVs.

As of December 2018, there are 39 public hydrogen stations in the United States, with 33 retail stations in California (AFDC 2018). Hydrogen infrastructure is also expanding internationally, with 232 active stations outside of the United States (HyARC 2018; Alazemi and Andrews 2015). California is leading a group of states that have adopted regulations to increase alternative fuel vehicle market share and reduce transportation-related harmful emissions (State ZeroEmission Vehicle Programs 2013). These regulations provide incentives to increase alternative fuel vehicle sales, and hydrogen FCEVs are eligible for incentives to meet the state's goals. California Assembly Bill 8, which allocates funding for hydrogen stations and requires progress related to hydrogen station deployment, has proven essential in the support of the hydrogen infrastructure deployment goal of at least 100 publicly available stations (Baronas et al. 2017). The California Air Resources Board has completed three annual reviews of its fuel cell policy program, with the latest one in August 2017 (CARB 2017). The 2017 annual report includes nine major findings which covered station deployment, vehicle deployment, station economics, and long-term demand and growth with renewably generated hydrogen.

Previous technology validation work on FCEVs and hydrogen infrastructure was performed through the FCEV Learning Demonstration, also known as the Controlled Hydrogen Fleet and Infrastructure Demonstration and Validation Project. This was a large effort by DOE and industry that began in 2003 and ended in 2011. Vehicle OEMs and station providers teamed together to demonstrate hydrogen fuel cell technologies. That effort funded the technologies (cars and stations) while also providing data to NREL for analysis and reporting on key findings.

This evaluation project continued to track the progress of fuel cell electric vehicles leading up to and through their introduction. These data enable DOE to determine if targets are being met and provide feedback to its research and development efforts. 
Figure 2 shows the number of OEM participants in a calendar year (not vehicle model year or date of vehicle operation data) with additional breakdown of the different evaluation phases. This evaluation project corresponds to "LD3" in the figure. Some of the current partners were also in the Learning Demonstration; however, the vehicles and technologies are not necessarily the same as the vehicles currently under evaluation even though some of the vehicle body platforms are the same.

FCEV Evaluation Phases

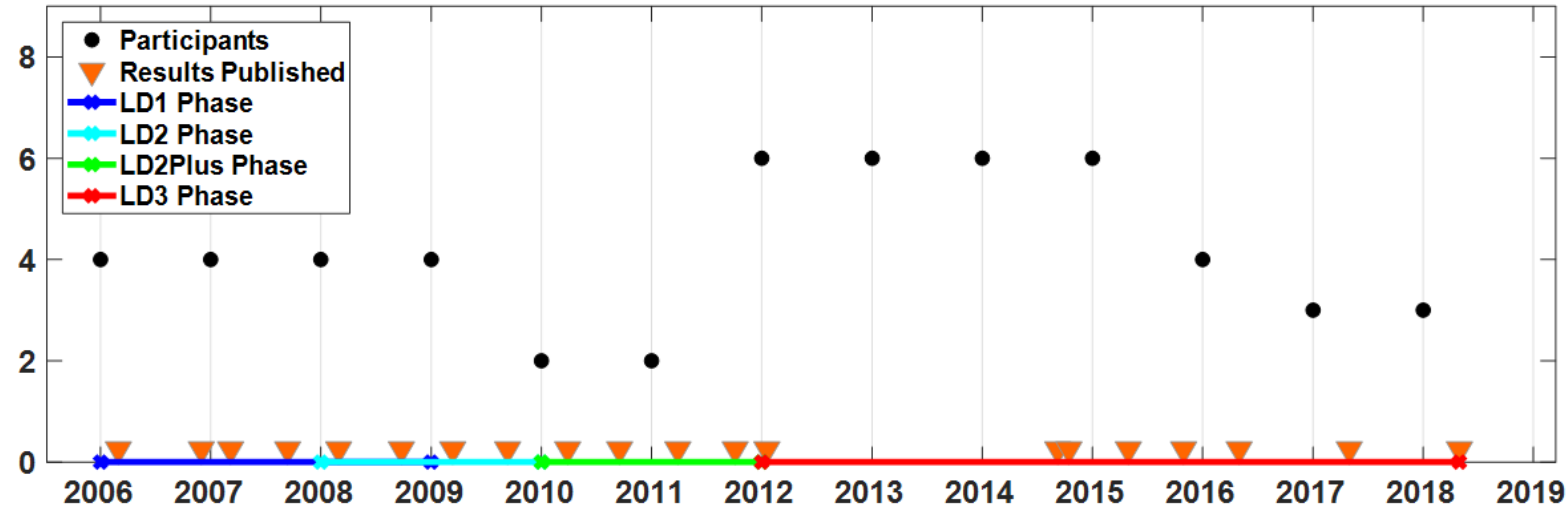

Figure 2. OEM participation timeline

\section{Evaluation Approach}

Working in collaboration with DOE and industry project partners, NREL acts as the central data repository for the data collected from fuel cell demonstration projects, including assessments of FCEVs, hydrogen fueling infrastructure, fuel cell buses, fuel cell powered material handling equipment, stationary power, and fuel cell backup power. To protect proprietary and businesssensitive data that have been supplied by industry partners, DOE's Fuel Cell Technologies Office within the office of EERE established the NFCTEC at NREL to house sensitive data and enable data analysis. The NFCTEC is a secure, off-network room with access provided to a small set of approved users.

The project partners collect operation, maintenance, and safety data for fuel cell system(s) and accompanying infrastructure. NREL receives the data quarterly and stores, processes, and analyzes the data in the NFCTEC. An internally developed tool, the NREL Fleet Analysis Toolkit (NRELFAT), is used for this data processing, analysis, and reporting.

Individual system, fleet, and site analysis results are aggregated into public results called composite data products (CDPs) that show the status and progress of the technology without identifying individual companies or revealing proprietary information. Prior to publication, the project's industry partners review the CDPs and provide their input and approval. CDPs enable NREL to publish in-depth analyses without identifying individual companies or their performance. These CDPs report on the progress of the technology and the deployment projects, focusing on the most significant results. They are published on the NREL website ${ }^{1}$ and published at industry-relevant conferences. While the raw data are secured by NREL to protect

\footnotetext{
${ }^{1}$ https://www.nrel.gov/hydrogen/technology-validation.html
} 
commercially sensitive and proprietary information, individualized data analysis results are provided as detailed data products (DDPs) to the partners who supplied the data. These DDPs identify individual contributions to CDPs and are intended to assist companies as they refine and improve fuel cell technologies but are not made available to the public. Figure 3 illustrates the NFCTEC approach.

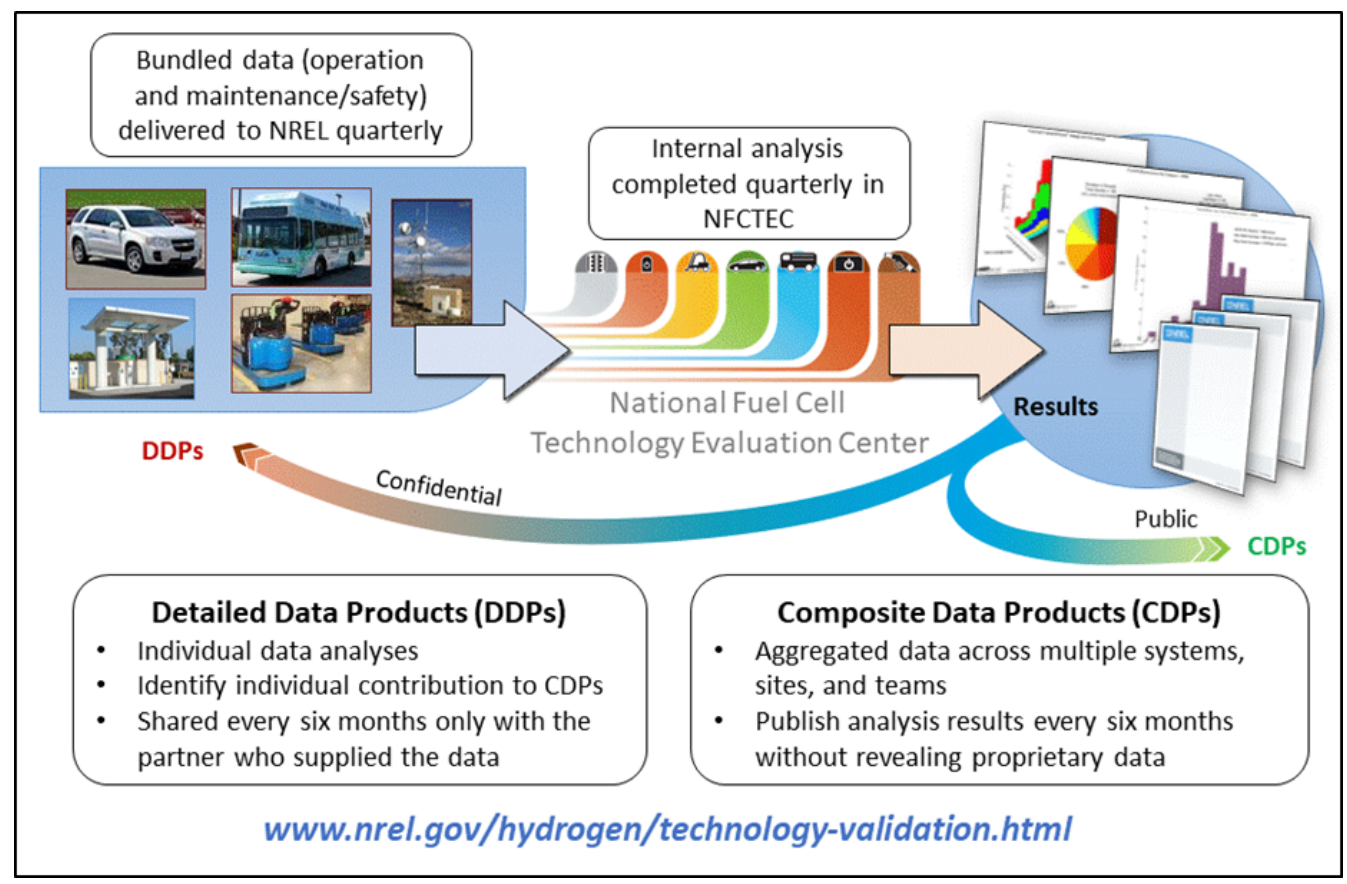

Figure 3. NREL's aggregated data analysis using the NFCTEC

\section{Summary of Results}

Since 2006, NREL's NFCTEC has completed analysis of 230 on-road vehicles that have accumulated more than 7.4 million miles. All data results presented here are for the current evaluation, unless specifically attributed to the Learning Demonstration.

The current FCEV technology advancements and technology generations are varied between the OEMs because of their individual development and production schedules. The current FCEV evaluation analyses include the following categories: durability, deployment (e.g., number of vehicles included), system specifications, range, fuel economy, efficiency, fill performance, reliability, drive and fill behaviors, power and energy management, fuel cell transients (e.g., frequency of rapid increases or decreases in fuel cell power), emissions, and benchmarking against technical targets and typical gasoline vehicle operation. All of the public results are available on NREL's FCEV evaluation website. ${ }^{2}$

Fuel cell durability has steadily and significantly improved over the last decade, and on-road fuel economy and actual driving range between fills have also increased since 2006. NREL observed FCEVs operating in similar ways to traditional gasoline vehicles for driving and fueling, yet there are some behaviors that are more representative of fleet FCEV operation instead of use by

\footnotetext{
${ }^{2}$ https://www.nrel.gov/hydrogen/fuel-cell-vehicle-evaluation.html
} 
individual drivers. Analysis results show progress against key DOE metrics of voltage durability, system gravimetric and volumetric capacity, specific power, and power density.

Figure 4 presents results in comparison to key DOE metrics and table of this information can be referenced in the Appendix. The FCEV performance and specifications have made good progress, without sacrificing efficiency and capability, since NREL started studying the technology in 2006.

Summary of Key FCEV Metrics vs DOE Targets ${ }^{a}$
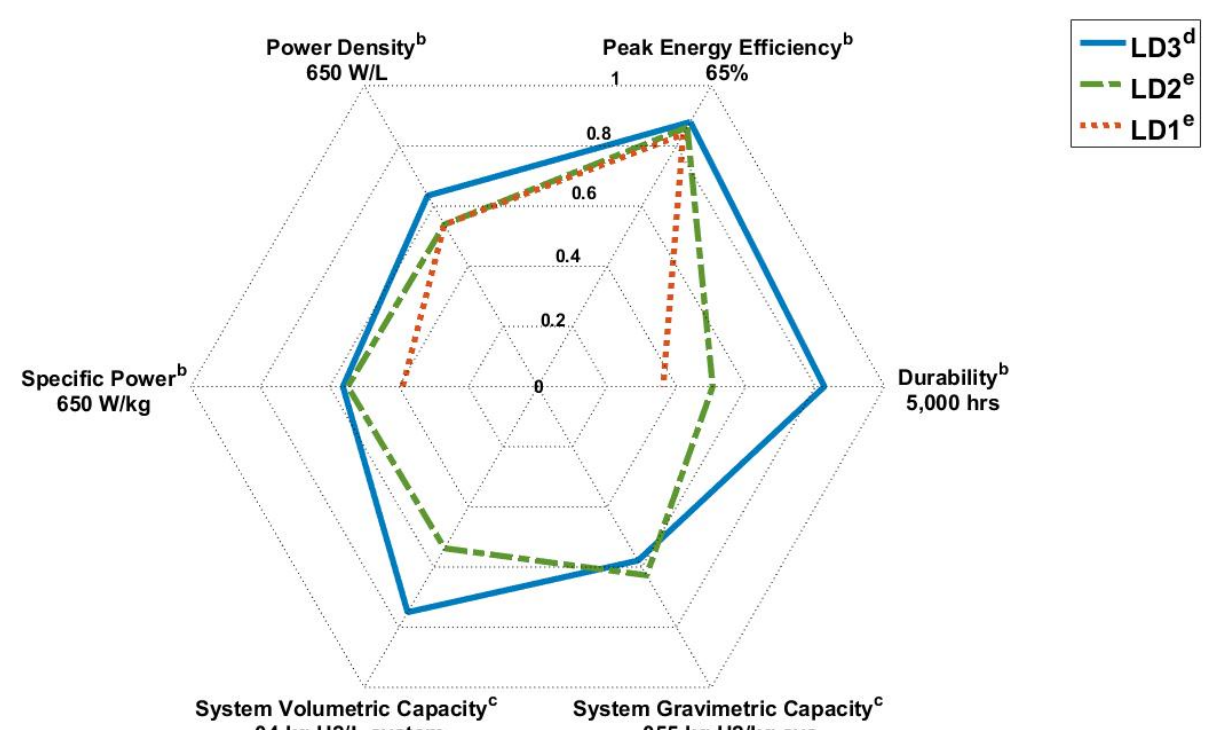

$.04 \mathrm{~kg} \mathrm{H} 2 / \mathrm{L}$ system $\quad .055 \mathrm{~kg} \mathrm{H} 2 / \mathrm{kg}$ sys

a. Results are a fraction of the 2020 targets in the Fuel Cell Technolgies Office Multi-Year Research, Development, and Demonstration (MYRDD) Plan (https://energy.gov/eere/fuelcells/downloads/fuel-cell-technologies-office-multi-year-research-development-and-22)

b. Analyzed 700 Bar storage systems. LD1 volumetric and gravimetric capacties excluded due to 350 Bar storage systems.

c. MYRDD Fuel Cell section 3.4 (last updated May 2017), table 3.4.3.

d. MYRDD Hydrogen Storage section 3.3 (last updated May 2015), table 3.3.3.

e. Current results are available at http://www.nrel.gov/hydrogen/proj_fc_vehicle_evaluation.html (Updated 4/2018)

f. National Fuel Cell Vehicle Learning Demonstration Final Report (http://www.nrel.gov/hydrogen/pdfs/54860.pdf)

Figure 4. Summary of key FCEV metrics vs. DOE targets ${ }^{a}$

\section{Conclusions}

Over the last 10 years, NFCTEC has completed analysis of 230 on-road vehicles that have accumulated more than 7 million miles. The current data analyzed come from 47 vehicles and 3 OEMs, with model years spanning 2008 to 2017 . Fuel cell durability has steadily and significantly improved over the last decade, and on-road fuel economy and actual driving range between fills have also increased over the last 10 years.

Two parameters used in this evaluation project to track and validate system durability are projected operation time to $10 \%$ voltage degradation and actual operation hours. Fuel cell durability results were initially published in 2006 (the first generation of the Learning Demonstration project). The durability increased 1.5 times since 2006 . The maximum vehicle odometer is 296,300 miles (approximately 10\% of vehicles have passed 100,000 miles) and the maximum fuel cell operation hour is 5,605. 
The on-road fuel economy has also increased. The minimum and maximum on-road fuel economy is 34 and 57.5 miles per kilogram hydrogen. Overall, the current evaluation indicates an improvement of approximately $30 \%$ from the first-generation Learning Demonstration (LD1) results. Another positive trend over the last decade of NFCTEC-analyzed FCEV operation is the actual distance driven between fueling. The results show that the median distance between fueling events was 56 miles for 2005-2007, 81 miles for 2007-2009, and 98 miles for 20102011. The median distance driven between fueling has over doubled with the median tank level at fill at $30 \%$.

Both driving and fueling trends have been compared with conventional gasoline trends. A few differences (like daily distance traveled and weekend fueling) have been observed in those comparisons. This is an indication that FCEV drivers are utilizing vehicles just as they would any other vehicle. On-board tank fueling data support understanding of station fueling performance from the perspective of the vehicle and are used to understand the actual range of tank temperatures with the expected extreme temperature conditions at a fill.

Overall, this project addressed the critical need for data analytics to inform both early-stage R\&D and commercial readiness of hydrogen vehicle and station technologies. NREL will continue to analyze hydrogen fueling infrastructure through partnerships with DOE and California agencies. Additional information gathered will be used to help drive industry- and DOE-funded early-stage research and development. NREL's website ${ }^{3}$ will continue to be the primary repository for NFCTEC's hydrogen fuel cell vehicle and infrastructure analysis results, as well as results from technology validation of other hydrogen components and systems.

\footnotetext{
${ }^{3}$ https://www.nrel.gov/hydrogen/fuel-cell-vehicle-evaluation.html
} 


\section{References}

AFDC (Alternative Fuels Data Center). 2018. Alternative Fueling Station Locator. Washington, DC: U.S. Department of Energy. Accessed April 23, 2018.

https://www.afdc.energy.gov/stations/.

Alazemi, J. and J. Andrews. 2015. "Automotive hydrogen fuelling stations: An international review.” Renew. Sustain. Energy Rev., vol. 48, pp. 483-499.

Andress, D., T. Nguyen, and G. Morrison. 2016. "GHG Emissions and Petroleum Use Reduction from Fuel Cell Deployments.” DOE Hydrogen and Fuel Cells Program Record 16003.

Washington, DC: U.S. Department of Energy.

Baronas, Jean, Gerhard Achtelik, et al. 2017. Joint Agency Staff Report on Assembly Bill 8: 2016 Annual Assessment of Time and Cost Needed to Attain 100 Hydrogen Refueling Stations in California. California Energy Commission. Publication Number: CEC-600-2017-002.

CARB (California Air Resources Board). 2017. 2017 Annual Evaluation of Hydrogen Fuel Cell Electric Vehicle Deployment and Hydrogen Fuel Station Network Development. Sacramento, CA: California Air Resources Board.

Carlson, E. J., J. H. Thijssen, S. Lasher, S. Sriramulu, G. C. Stevens, and N. Garland. 2002. "Cost Modeling of PEM Fuel Cell Systems for Automobiles," SAE Tech. Pap. 2002-01-1930.

Chen, T. 2008. Hydrogen Delivery Infrastructure Options Analysis. Nexant. https://energy.gov/sites/prod/files/2014/03/f11/delivery_infrastructure_analysis.pdf.

Davis, P. 2006. “Fuel Cell System Cost - 2002 vs. 2005.” DOE Hydrogen and Fuel Cells Program Record 5005. Washington, DC: U.S. Department of Energy.

DOE (U.S. Department of Energy). 2015. Fuel Cell Technologies Office Multi-Year Research, Development, and Demonstration Plan. Technology Validation chapter. Washington, DC: U.S. Department of Energy. https://energy.gov/eere/fuelcells/downloads/fuel-cell-technologies-officemulti-year-research-development-and-22.

DOE (U.S. Department of Energy). 2012. Fuel Cell Technologies Office Multi-Year Research, Development, and Demonstration Plan. Fuel Cells chapter, Table 3.4.3 Technical targets for automotive application. Washington, DC: U.S. Department of Energy. Accessed October 13, 2014. https://energy.gov/eere/fuelcells/downloads/fuel-cell-technologies-office-multi-yearresearch-development-and-22.

Fuel Cells Bulletin. 2016. "Honda begins sales of Clarity Fuel Cell, first car delivered to METI." Fuel Cells Bull., vol. 2016, no. 4, p. 2.

Governor's Interagency Working Group on Zero-Emission Vehicles. 2016. "2016 ZEV Action Plan: An Updated Roadmap Toward 1.5 Million Zero-Emission Vehicles on California Roadways by 2025." Sacramento, CA: Governor's Interagency Working Group on ZeroEmission Vehicles. 
Hartline, J. and S. Ingram. 2015. "First Toyota Mirai Owners Get a Jump on the Future." ToyotaUSA Newsroom. Accessed March 3, 2017.

http://toyotanews.pressroom.toyota.com/releases/toyota+mirai+owners+jump+future.htm.

HyARC (Hydrogen Analysis Resource Center). 2018. "International Hydrogen Fueling Stations." Accessed April 23, 2018. https://www.h2tools.org/hyarc/data/hydrogen-delivery.

Nguyen, T. and J. Ward. 2016. "Life-Cycle Greenhouse Gas Emissions and Petroleum Use for Current Cars." DOE Hydrogen and Fuel Cells Program Record 16004. Washington, DC: U.S. Department of Energy.

NREL. 2018. "Fuel Cell and Hydrogen Technology Validation." National Renewable Energy Laboratory. https://www.nrel.gov/hydrogen/technology-validation.html.

State Zero-Emission Vehicle Programs. 2013. State Zero-Emission Vehicles Programs: Memorandum of Understanding.

Trainor, J. and D. Joyce. 2016. "Capitol Hyundai of San Jose Celebrates First Fuel Cell Customer Delivery in Northern California." Hyundai News. Accessed March 3, 2017. http://www.hyundainews.com/us/en/media/pressreleases/45378/capitol-hyundai-of-san-josecelebrates-first-fuel-cell-customer-delivery-in-northern-california.

Wilson, A., J. Marcinkoski, and D. Papageorgopoulos, 2016a. "Fuel Cell System Cost - 2016." DOE Hydrogen and Fuel Cell Program Record 16020. Washington, DC: U.S. Department of Energy.

Wilson, A., J. Marcinkoski, and D. Papageorgopoulos. 2016b. "On-Road Fuel Cell Stack Durability.” DOE Hydrogen and Fuel Cells Program Record 16019. Washington, DC: U.S. Department of Energy.

Wipke, K., S. Sprik, J. Kurtz, T. Ramsden, C. Ainscough, and G. Saur. 2012. National Fuel Cell Electric Vehicle Learning Demonstration Final Report. NREL/TP-5600-54860. Golden, CO: National Renewable Energy Laboratory. https://www.nrel.gov/docs/fy12osti/54860.pdf. 


\section{Publications and Presentations}

The following publications provide more information about NREL's fuel cell electric vehicle evaluation activities and capabilities. See the Learning Demonstration final report (Wipke et al. 2012) for a list of technical results, papers, and presentations going back to 2004.

\section{Composite Data Products}

Kurtz, Jennifer, Sam Sprik, Chris Ainscough, Genevieve Saur, and Shaun Onorato. "Fuel Cell Electric Vehicle Performance Composite Data Products: Spring 2018." Golden, CO: NREL, May 2018. https://www.nrel.gov/docs/fy18osti/71643.pdf.

Kurtz, Jennifer, Sam Sprik, Chris Ainscough, and Genevieve Saur. "Fuel Cell Electric Vehicle (FCEV) Performance Composite Data Products: Spring 2017." Golden, CO: NREL, May 2017. https://www.nrel.gov/docs/fy17osti/68647.pdf.

Kurtz, Jennifer, Sam Sprik, Chris Ainscough, Genevieve Saur, and Matthew Jeffers. Fuel Cell Electric Vehicle (FCEV) Performance Composite Data Products: Spring 2016. Golden, CO: NREL, May 2016. https://www.nrel.gov/docs/fy16osti/66578.pdf.

\section{Conference and Meeting Presentations}

Kurtz, Jennifer, Chris Ainscough, Genevieve Saur, Sam Sprik, and Shaun Onorato. "Fuel Cell Electric Vehicle Evaluation.” DOE Hydrogen and Fuel Cells Program 2018 Annual Merit Review and Peer Evaluation Meeting, June 2018. https://www.hydrogen.energy.gov/pdfs/review18/tv001_kurtz_2018_p.pdf.

Kurtz, Jennifer, Sam Sprik, Chris Ainscough, and Genevieve Saur. "Fuel Cell Electric Vehicle Evaluation.” DOE Hydrogen and Fuel Cells Program 2017 Annual Merit Review and Peer Evaluation Meeting, June 2017. https://www.hydrogen.energy.gov/pdfs/review17/tv001_kurtz_2017_o.pdf.

Kurtz, Jennifer, Sam Sprik, Chris Ainscough, Genevieve Saur, and Matt Jeffers. "Fuel Cell Electric Vehicle Evaluation.” Advanced Automotive Battery Conference, June 2016. https://www.nrel.gov/docs/fy16osti/66760.pdf.

Kurtz, Jennifer, Sam Sprik, Chris Ainscough, Genevieve Saur, and Matt Jeffers. "Fuel Cell Electric Vehicle Evaluation.” DOE Hydrogen and Fuel Cells Program 2016 Annual Merit Review and Peer Evaluation Meeting, June 2016. https://www.hydrogen.energy.gov/pdfs/review16/tv001_kurtz_2016_o.pdf.

Kurtz, Jennifer, Sam Sprik, Chris Ainscough, and Genevieve Saur. "Fuel Cell Electric Vehicle (FCEV) Evaluation.” Interagency Working Group Meeting, December 2015. https://www.nrel.gov/docs/fy16osti/66609.pdf.

Performance Status of Hydrogen Stations and Fuel Cell Vehicles, Sam Sprik, Jennifer Kurtz, Chris Ainscough, Michael Peters, Matt Jeffers, and Genevieve Saur, Presented at the 2015 Fuel Cell Seminar \& Energy Exposition (November 2015).

https://www.nrel.gov/docs/fy16osti/66615.pdf. 
Kurtz, Jennifer, Sam Sprik, Chris Ainscough, and Genevieve Saur. "Fuel Cell Electric Vehicle Evaluation." DOE Hydrogen and Fuel Cells Program 2015 Annual Merit Review and Peer Evaluation Meeting, June 2015.

https://www.hydrogen.energy.gov/pdfs/review15/tv001_kurtz_2015_o.pdf.

Kurtz, Jennifer, Sam Sprik, and Mike Peters. "Fuel Cell Electric Vehicle Evaluation.” DOE Hydrogen and Fuel Cells Program 2014 Annual Merit Review and Peer Evaluation Meeting, June 2014. https://www.hydrogen.energy.gov/pdfs/review14/tv001 kurtz 2014 p.pdf.

Sprik, Sam, Jennifer Kurtz, Keith Wipke, Genevieve Saur, and Chris Ainscough. "Technology Validation of Fuel Cell Vehicles and Their Hydrogen Infrastructure.” 2013 Fuel Cell Seminar, November 2013. https://www.nrel.gov/docs/fy14osti/60876.pdf.

Kurtz, Jennifer, Keith Wipke, Sam Sprik, Chris Ainscough, and Genevieve Saur. "Fuel Cell Electric Vehicle Evaluation.” DOE Hydrogen and Fuel Cells Program 2013 Annual Merit Review and Peer Evaluation Meeting, May 2013. https://www.hydrogen.energy.gov/pdfs/review13/tv001_kurtz_2013_p.pdf.

\section{Annual Progress Reports}

Kurtz, Jennifer, Sam Sprik, Chris Ainscough, and Genevieve Saur. "Fuel Cell Electric Vehicle Evaluation." Excerpt from the DOE Hydrogen and Fuel Cells Program 2017 Annual Progress Report. Washington, DC: U.S. Department of Energy, May 2018.

https://www.hydrogen.energy.gov/pdfs/progress17/vii_a_1_kurtz_2017.pdf.

Kurtz, Jennifer, Sam Sprik, Chris Ainscough, and Genevieve Saur. "Fuel Cell Electric Vehicle Evaluation." Excerpt from the DOE Hydrogen and Fuel Cells Program 2016 Annual Progress Report. Washington, DC: U.S. Department of Energy, February 2017. https://www.hydrogen.energy.gov/pdfs/progress16/vii_a_1_kurtz_2016.pdf.

Kurtz, Jennifer, Sam Sprik, Chris Ainscough, and Genevieve Saur. "Fuel Cell Electric Vehicle Evaluation." Excerpt from the DOE Hydrogen and Fuel Cells Program 2015 Annual Progress Report. Washington, DC: U.S. Department of Energy, December 2015.

https://www.hydrogen.energy.gov/pdfs/progress15/vii 4 kurtz 2015.pdf.

Kurtz, Jennifer, Sam Sprik, and Mike Peters. "Fuel Cell Electric Vehicle Evaluation.” Excerpt from the DOE Hydrogen and Fuel Cells Program 2014 Annual Progress Report. Washington, DC: U.S. Department of Energy, November 2014.

https://www.hydrogen.energy.gov/pdfs/progress14/vii_a_7_kurtz_2014.pdf.

Kurtz, Jennifer, Keith Wipke, Sam Sprik, Genevieve Saur, and Chris Ainscough. "Fuel Cell Electric Vehicle Evaluation." Excerpt from the DOE Hydrogen and Fuel Cells Program 2013 Annual Progress Report. Washington, DC: U.S. Department of Energy, December 2013. https://www.hydrogen.energy.gov/pdfs/progress13/vii_7_kurtz_2013.pdf. 


\section{Appendix}

Table A-1. FCEV Evaluation Key Metrics and Status

\begin{tabular}{|c|c|c|c|c|c|}
\hline Vehicle Performance Metrics & $\begin{array}{l}\text { DOE } \\
\text { Target } \\
\text { (Year } \\
\text { 2020) }\end{array}$ & LD3 $^{b}$ & LD2+c & LD2 $^{c}$ & LD1 $^{c}$ \\
\hline \multicolumn{6}{|l|}{ Durability } \\
\hline $\begin{array}{l}\text { Max fuel cell durability projection } \\
\text { (hours) }\end{array}$ & 5,000 & 4,130 & -- & 2,521 & 1,807 \\
\hline $\begin{array}{l}\text { Average fuel cell durability } \\
\text { projection (hours) }\end{array}$ & & 2,442 & 1,748 & 1,062 & 821 \\
\hline Max fuel cell operation (hours) & & 5,648 & 1,582 & 1,261 & 2,375 \\
\hline \multicolumn{6}{|l|}{ Efficiency } \\
\hline $\begin{array}{l}\text { Adjusted dyno range (miles) } \\
\text { (window sticker) }\end{array}$ & & $200-320$ & -- & 196-254 & $103-190$ \\
\hline $\begin{array}{l}\text { Median on-road distance } \\
\text { between fuelings (miles) }\end{array}$ & & 122 miles & 98 & 81 & 56 \\
\hline $\begin{array}{l}\text { Fuel economy (mi/kg) } \\
\text { (window sticker) }\end{array}$ & & 52 (median) & -- & $43-58$ & $42-57$ \\
\hline Fuel cell efficiency at $1 / 4$ power & $65 \%$ & $57 \%$ (average) & -- & $\begin{array}{l}53 \%-59 \% \\
(\max )\end{array}$ & $51 \%-58 \%$ \\
\hline Fuel cell efficiency at full power & & $43 \%$ (average) & -- & $42 \%-53 \%$ & $30 \%-54 \%$ \\
\hline \multicolumn{6}{|l|}{ Specs } \\
\hline Specific power (W/kg) & 650 & $240-563$ & -- & $306-406$ & $183-323$ \\
\hline Power density (W/L) & 850 & $278-619$ & -- & $300-400$ & $300-400$ \\
\hline \multicolumn{6}{|l|}{ Storage } \\
\hline $\begin{array}{l}\text { System gravimetric capacity } \\
\text { (kg H2/kg system) }\end{array}$ & $5.5 \%$ & $2.5 \%-3.7 \%$ & -- & -- & $2.5 \%-4.4 \%$ \\
\hline $\begin{array}{l}\text { System volumetric capacity } \\
\text { (kg H2/L system) }\end{array}$ & 0.04 & $0.018-0.054$ & -- & -- & $0.017-0.025$ \\
\hline \multicolumn{6}{|c|}{$\begin{array}{l}\text { a Fuel Cell Technologies Office Multi-Year Research, Development, and Demonstration Plan (DOE 2012) } \\
\text { b Current results are available online (NREL 2018) (updated May 2018) from Learning Demonstration } 3 \text { (LD3) } \\
{ }^{c} \text { National Fuel Cell Vehicle Learning Demonstration (LD) Final Report (Wipke et al. 2012) which included two more } \\
\text { phases Learning Demonstration } 2 \text { (LD2) and Learning Demonstration 2+ (LD2+) that had different generation } \\
\text { vehicles and number of participating OEMs }\end{array}$} \\
\hline
\end{tabular}


Data sources were supplied by partners and aggregated to show minimum and maximum vehicle specifications.
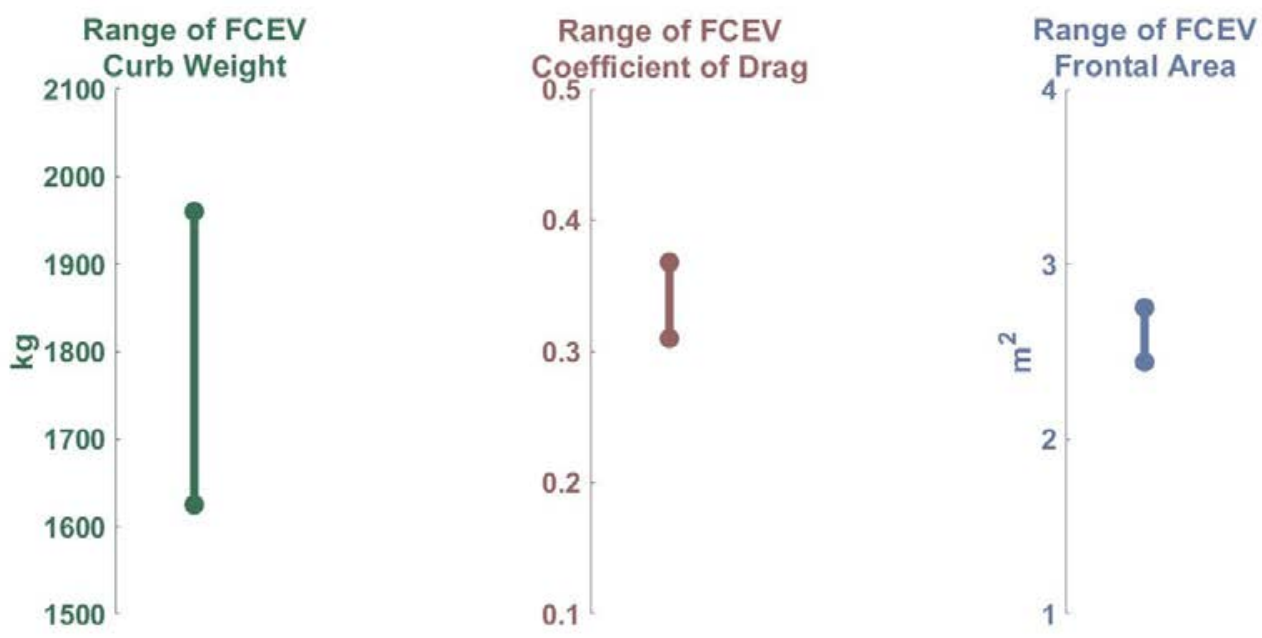

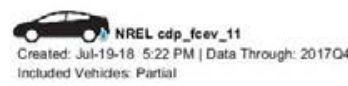

Figure A-1. FCEV size metrics in evaluation project
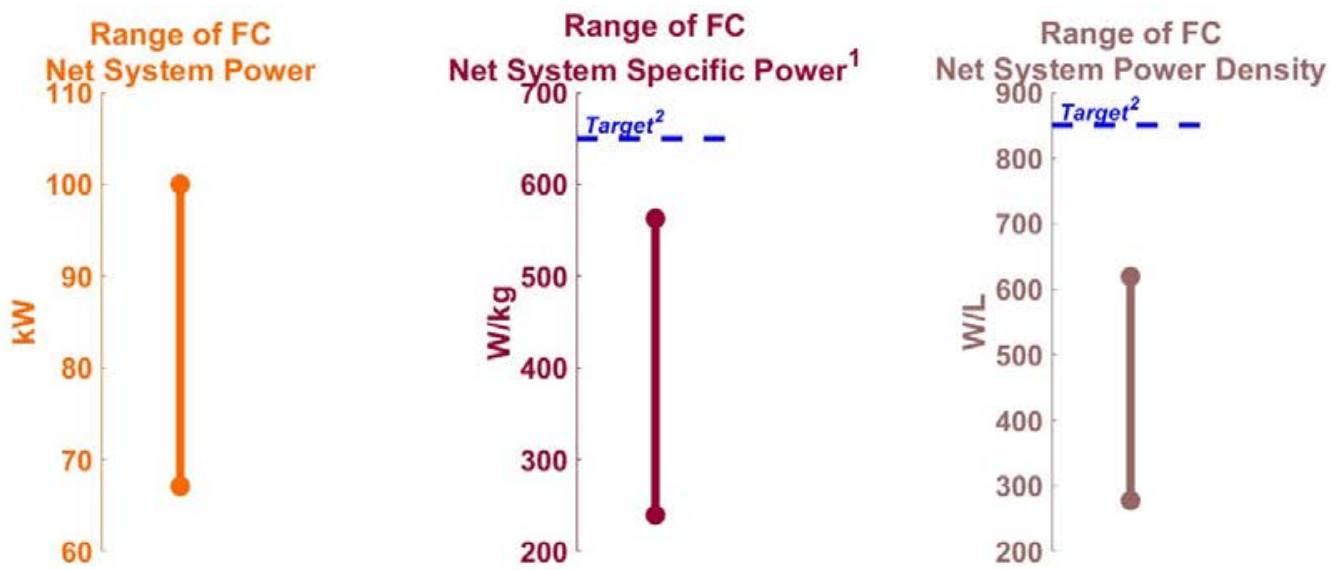

1) Fuel cell system includes fuel cell stack and balance of plant. Hydrogen storage, battery storage, power electronics, and electric drive are not included. 2) 2020 DOE technical target Table 3.4 .3

2) 2020 DOE technical target Table 3.4 .3
(www.energy.gov/sites/prod/files/2014/12/f19/fcto myrdd fuel cells.pdf)

Figure A-2. FCEV power metrics in evaluation project 